\title{
Bancroftian filariasis associated with male sterility
}

\author{
Dwijesh Kumar Panda, ${ }^{1}$ Devi Prasad Mohapatra ${ }^{2}$
}

${ }^{1}$ Department of Pathology and Medicine, Sanaria, Bhubaneswar, India ${ }^{2}$ Department of Plastic Surgery, JIPMER, Puducherry, India

\section{Correspondence to}

Dr Dwijesh Kumar Panda, doctordwijesh@yahoo.com

Accepted 21 December 2017

\section{DESCRIPTION}

A 33-year-old man presented with recurrent pain and swelling in the inguinal region since the last 8 years, occasional fever and loss of sex drive. The pain and swelling usually lasted for 2-3 weeks with a pain-free interval of 4-5 months. He felt that the size of the left testis is gradually reducing. $\mathrm{He}$ had been married for more than 5 years without having any children. Clinical examination revealed swelling and tenderness of the scrotum more on the right (figure 1A).

Ultrasound examination showed swelling of both epididymis with the outer area appearing irregularly echogenic due to fibrosis (figure 1B). The right cord appeared swollen and measured $8.75 \mathrm{~mm}$, normal being below $5 \mathrm{~mm}$. A colour Doppler study revealed absence of vascular flow on the right side testis (figure 1C).

Seminal fluid analysis was done. The total sperm count was 9.4 million/mL having low viscosity with non-motile dead spermatozoa about $40 \%$. The circulating adult filarial antigen test (OG4C3) was positive (512 antigen units). OG4C3 test is a highly sensitive and specific quantitative monoclonal antibody-based ELISA test for the diagnosis of filariasis.

A diagnosis of right filarial funiculitis with bilateral chronic epididymitis and secondary infertility was made. The patient was treated with amoxicillin and clavulanic acid $2 \mathrm{~g}$ daily, orally for 1 week, along with a course of diethylcarbamazine for 2 weeks as recommended by WHO guidelines. Flavonoid supplements were added for 2 weeks to reduce inflammation and pain. Following therapy, the

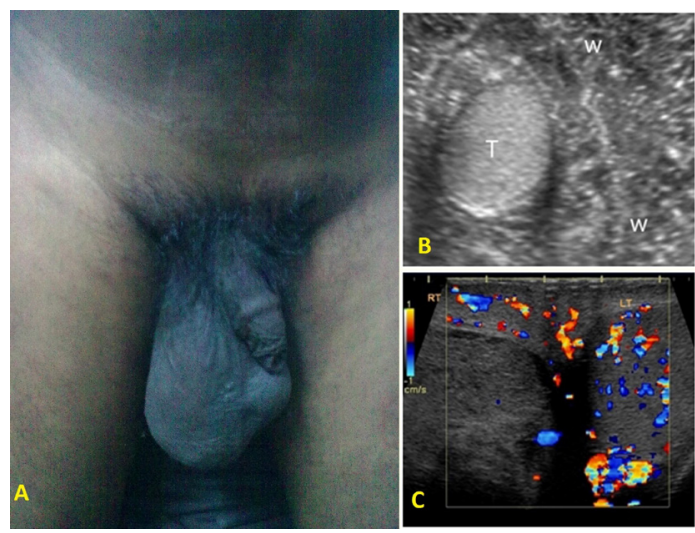

Fro Figure 1 (A) A 33-year- old man with right-sided testicular swelling. (B) Ultrasonography of the scrotum reveals a hypoechogenic, small right testis with irregularly echogenicity in periphery due to fibrosis. (C) Colour Doppler reveals absence of vascular flow on right-side testis. patient had symptomatic relief of pain and fever, with reduction in swelling over right testis over a period of 6 months. A repeat seminal fluid analysis after 6 months however revealed a marginal improvement in sperm count ( 10 million $/ \mathrm{mL})$.

Lymphatic filariasis, most commonly due to Wuchereria bancrofti, is responsible for affecting nearly 120 million people worldwide and disfiguring another 40 million people. ${ }^{1}$ The adult filarial worm resides in the lymphatic system and disturbs the normal lymphatic function. Genital manifestations of lymphatic filariasis in men include hydrocele, lymphorea, epididymo-orchitis, ram horn penis and infertility. ${ }^{2}$ The exact mechanism of infertility in filariasis is unknown. Frequent epididymal inflammation and scarring leading to blockage of tubules may cause obstructive azoospermia. Development of antispermatozoa antibodies may also be a cause. $^{3}$

This manuscript highlights the devastating complication of infertility that may occur in untreated or late-treated bancroftian filariasis.

\section{Learning points}

- Lymphatic filariasis may present with numerous genital manifestations resulting in disfigurement and psychosexual abnormalities.

- Secondary infertility may be an incapacitating and devastating outcome of genital involvement in lymphatic filariasis.

- Lymphatic filariasis should be considered strongly as a differential diagnosis in patients with genital inflammation and swelling in endemic areas.

Contributors DKP and DPM were involved in literature review and manuscript preparation. Both authors have evaluated the final manuscript before submission.

Competing interests None declared.

Patient consent Obtained.

Provenance and peer review Not commissioned; externally peer reviewed.

(c) BMJ Publishing Group Ltd (unless otherwise stated in the text of the article) 2018. All rights reserved. No commercial use is permitted unless otherwise expressly granted.

\section{REFERENCES}

1 Global programme to eliminate lymphatic filariasis: progress report 2016. Wkly Epidemiol Rec 2017;92:594-607. English, French. Available from http://apps.who.int/iris/bitstream/10665/259184/1/ WER9240.pdf?ua $=1$

Mohapatra DP. BMJ Case Rep Published Online First: [please include Day Month Year]. doi:10.1136/bcr-2017223236
2 Manokaran G. Management of genital manifestations of lymphatic filariasis. Indian Journal of Urology 2005;21:39-43. http://www.

3 Kumar R. Surgery for azoospermia in the Indian patient: Why is it different? Indian J Urol 2011;27:98-101. indianjurol.com/text.asp?2005/21/1/39/19550. 
Copyright 2017 BMJ Publishing Group. All rights reserved. For permission to reuse any of this content visit http://group.bmj.com/group/rights-licensing/permissions.

BMJ Case Report Fellows may re-use this article for personal use and teaching without any further permission.

Become a Fellow of BMJ Case Reports today and you can:

- Submit as many cases as you like

- Enjoy fast sympathetic peer review and rapid publication of accepted articles

Access all the published articles

- Re-use any of the published material for personal use and teaching without further permission

For information on Institutional Fellowships contact consortiasales@bmjgroup.com

Visit casereports.bmj.com for more articles like this and to become a Fellow 